July 2006

\title{
A New Chapter of Irony: The Legal Implications of the Darfur Genocide Determination
}

Jerry Fowler

Follow this and additional works at: https://digitalcommons.usf.edu/gsp

\section{Recommended Citation}

Fowler, Jerry (2006) "A New Chapter of Irony: The Legal Implications of the Darfur Genocide Determination," Genocide Studies and Prevention: An International Journal: Vol. 1: Iss. 1: Article 7. Available at: https://digitalcommons.usf.edu/gsp/vol1/iss1/7

This Articles is brought to you for free and open access by the Open Access Journals at Digital Commons @ University of South Florida. It has been accepted for inclusion in Genocide Studies and Prevention: An International Journal by an authorized editor of Digital Commons @ University of South Florida. For more information, please contact digitalcommons@usf.edu. 


\title{
A New Chapter of Irony: The Legal Implications of the Darfur Genocide Determination
}

\author{
Jerry Fowler \\ Committee on Conscience, United States Holocaust \\ Memorial Museum ${ }^{1}$
}

\begin{abstract}
US Secretary of State Colin Powell determined that genocide as defined in the UN Genocide Convention had occurred in Darfur, but he disclaimed any new obligations as a result of that determination. Under the permissive provisions of Article 8 of the convention, he called upon the UN Security Council to investigate whether genocide or other crimes were being committed, with a view to accountability. The subsequent investigation by a UN Commission of Inquiry concluded, on rather dubious grounds, that the Sudanese government was not responsible for genocide but recommended referral of the situation to the International Criminal Court for purposes of accountability; ironically, the opposite conclusions of Powell and the UN Commission produced the same result: a call for steps toward accountability. A further irony is that the UN Convention, although articulating an international condemnation of the crime of genocide, compels nothing more. The attempts at the September 2005 World Summit to obtain recognition of an international responsibility to protect underscored the fundamental reality that nations will not act decisively to confront genocide and other massive human rights abuses out of a sense of legal obligation, but only as a matter of political and practical necessity.
\end{abstract}

Legal scholar Diane Orentlicher once observed that the United Nations Convention on the Prevention and Punishment of the Crime of Genocide (UNCG) "has come to embody the conscience of humanity."2 She then acidly remarked that the convention's "moral force is surely ironic," in light of the persistent failure of governments to enforce its terms. ${ }^{3}$ Darfur adds another sad chapter of irony in the convention's history, given the dramatic incongruity between the sense of urgency that one might expect a plausible case of ongoing genocide to engender and the relatively lackadaisical international political response that has in fact unfolded. As it turns out, this irony is embedded in the provisions of the UNCG itself. After calling for international cooperation "to liberate mankind from such an odious scourge," the convention proceeds to define the crime of genocide in terms that, from the perspective of "preventing" or "suppressing" genocide, are problematic. It then offers only the vaguest sense of what should be done when genocide is imminent or actually under way.

\section{"To Liberate Mankind from Such an Odious Scourge"}

Though there are examples of mass violence directed against identifiable groups dating back to antiquity, "genocide" as a term and a concept has a quite recent origin. Raphael Lemkin, a Jewish lawyer who fled Poland after the German invasion in 1939,

Jerry Fowler, "A New Chapter of Irony: The Legal Implications of the Darfur Genocide Determination." Genocide Studies and Prevention 1, 1 (July 2006): 29-40. (C) 2006

from Genocide in Darfur: Investigation into Atrocities in the Sudan edited by Samuel Totten and Eric Markusen. Reproduced by permission of Routledge/Taylor \& Francis Group, LLC. 
coined the word and introduced it in $1944 .{ }^{4}$ He derived it from the Greek for tribe or nation (geno-) and the Latin for killing (-cide). By "genocide," Lemkin meant "a coordinated plan of different actions aiming at the destruction of essential foundations of the life of national groups, with the aim of annihilating the groups themselves." 5

In no small part due to the efforts of Lemkin himself, his new word soon gained currency. ${ }^{6}$ It was mentioned in the 1945 Nuremberg indictment as a description of war crimes committed by the defendants being tried before the International Military Tribunal. ${ }^{7}$ In December 1946, the General Assembly of the newly created United Nations adopted a resolution that described genocide as "a denial of the right of existence of entire human groups" that "shocks the conscience of mankind" and "affirm[ed]" that genocide is "crime under international law."

That resolution also set in motion the process that resulted in the adoption of the UNCG on 9 December $1948 .^{9}$ The convention itself is rather a spare documentnineteen articles, of which the last nine are more technical than substantive, dealing with matters such as where states that become parties to the convention shall deposit their instruments of ratification or accession (with the secretary-general of the United Nations); how many states must become parties before the convention comes into force (twenty, a number reached in late 1950); and where the original copy of the convention would be held (in the UN archives).

The convention's preamble invokes "international law" and "the spirit and aims of the United Nations," as well as the condemnation of genocide "by the civilized world." It echoes the General Assembly's view that international cooperation is necessary to free humanity from the "odious scourge" of genocide. To that end, Article I specifies that "genocide, whether committed in time of peace or in time of war, is a crime under international law which [the Contracting Parties] undertake to prevent and to punish."

The heart of the substantive portion of the convention is Article II, which defines genocide as a matter of international law. The definition has two essential components: a specified physical act (what lawyers would call the actus reus) and a particular state of mind (technically, a mens rea). The specified acts cannot constitute genocide unless they are committed with the requisite state of mind.

The specified acts are the following:

(a) Killing members of the group;

(b) Causing serious bodily or mental harm to members of the group;

(c) Deliberately inflicting on the group conditions of life calculated to bring about its physical destruction in whole or in part;

(d) Imposing measures intended to prevent births within the group;

(e) Forcibly transferring children of the group to another group.

The required state of mind-which distinguishes genocide from any other crimeis the "intent to destroy, in whole or in part, a national, ethnical, racial or religious group, as such." Thus, merely intending to commit the specified acts is not enough. The perpetrators must also have a "specific" or "special" intent to destroy a protected group in whole or in part. ${ }^{10}$ Establishing the subjective intent harbored in the minds of perpetrators can present vexing issues of proof, especially when events are unfolding in some inaccessible location. As discussed more fully below, the circumstances surrounding the commission of specific acts can provide evidence of the intent with which those acts are committed. 
Several articles flesh out the central idea that genocide is an international crime, and therefore punishable. Article III explains that not only genocide itself but also "conspiracy to commit genocide," "direct and public incitement to commit genocide," "attempt to commit genocide," and "complicity in genocide" can be punished. According to Article IV, perpetrators are subject to punishment without regard to their status as "constitutionally responsible rulers" or holders of some other public office. In Article V, the parties "undertake" to pass whatever domestic legislation might be necessary to give effect to the terms of the convention, specifically emphasizing punishment for genocide and the other crimes listed in Article III. For good measure, Article VI adds an unspecified "international penal tribunal"11 as a possible venue for trying those accused of genocide, in addition to courts in the territory where the criminal acts were committed. ${ }^{12}$ Article VII addresses the extradition of accused perpetrators from one country in order to stand trial in another.

As terse as are the provisions related to punishment of genocide, the convention's other avowed goal-that of genocide prevention-gets even shorter shrift. Article VIII merely states that a party to the convention "may call upon the competent organs of the United Nations to take such action under the Charter of the United Nations as they consider appropriate for the prevention and suppression of acts of genocide" (emphasis added). Tossing the ball into the UN's court, in other words, is permitted but not required.

No other article refers to prevention, except for Article I's rather ambiguous statement that parties to the convention "undertake to prevent" genocide. Exactly what obligation this language imposes is not clear. Particularly opaque is whether the undertaking to prevent genocide is directed at a state's own territory or territory under its control or whether it imposes some duty on parties to act wherever in the world genocide might be threatened or occur. Some scholars have asserted the latter. ${ }^{13}$ Yet the language of the convention does not give any indication that such an extensive obligation was contemplated. Indeed, it would be quite bizarre to think that the drafters intended in 1948 to make intervention in the internal affairs of other states obligatory for individual states or groups of states (through the broad interpretation of Article I), while recourse to the United Nations is merely optional (under the plain terms of Article VIII). Such a scheme diverges wildly from the structure for maintaining international peace and security established just three years earlier with the adoption of the UN Charter and the creation of the United Nations itself. And in the almost six decades since the adoption of the UNCG, there is scant evidence of state practice evincing a sense of obligation to prevent or suppress genocide in other countries pursuant to Article I. When Bosnia argued before the International Court of Justice that all parties to the UNCG had a duty under Article I to prevent genocide against it and its citizens, the ad hoc judge appointed by Bosnia itself could only observe, rather morosely, that "the limited reaction of the parties to the Genocide Convention in relation [to past episodes of apparent genocide] may represent a practice suggesting the permissibility of inactivity."14 Likewise, the May 1994 internal State Department memorandum to US Secretary of State Warren Christopher recommending that the United States begin to use the word "genocide" in relation to Rwanda noted that such a move "would not have any particular legal consequences."15

\section{Is, Is Not}

The UNCG provided the framework within which US Secretary of State Colin Powell and the United States government considered, in mid-2004, the question of whether 
genocide was occurring in Darfur. Applying Article II's legal definition to the facts gathered by the Atrocities Documentation Team (ADT) and from other sources, they concluded that genocide had been committed and that the government of Sudan and its militia allies—-the so-called Janjaweed—were responsible. ${ }^{16}$

In announcing his determination, Secretary Powell pointed to murder, rape, and other physical violence committed against members of non-Arab ethnic groups. This violence corresponded with the acts specified in Article II (a) and (b) of the UNCGkilling members of a group and causing serious bodily or mental harm to them. He also pointed to the destruction of foodstuffs and other means of survival of the targeted groups, coupled with obstruction by the Sudanese government of the humanitarian assistance that the victims needed in order to survive. This conduct, which itself inflicted a large number of deaths on the targeted population in addition to those caused by direct violence, corresponded with article II(c)_deliberately inflicting conditions of life calculated to bring about a group's physical destruction, in whole or in part.

As for the "intent to destroy" required by Article II, Powell concluded that intent could be inferred from the Sudanese government's deliberate conduct. Inferring intent from conduct in the absence of direct evidence is widely accepted. The International Criminal Tribunal for Rwanda (ICTR), for example, has listed a number of circumstances that are relevant to determining "intent to destroy," many of which are present in the case of Darfur: "the general context of the perpetration of other culpable acts systematically directed against that same group"; "the scale of atrocities committed"; the "general nature" of the atrocities; deliberately and systematically targeting members of some groups but not others; attacks on (or perceived by the perpetrators to be attacks on) "the foundation of the group"; "the use of derogatory language toward members of the targeted group"; "the systematic manner of killing"; and "the relative proportionate scale of the actual or attempted destruction of a group." 17

In this regard, Powell's testimony to the Senate Foreign Relations Committee emphasized the scale and scope of the murder and rape of civilians as well as the fact that the actions of the Sudanese military and its militia allies were "a coordinated effort, not just random violence."18 Additionally, in the report released along with the testimony, the ADT's investigation documented substantial use of racial epithets and derogatory language directed against members of non-Arab ethnic groups in conjunction with violence. ${ }^{19}$ Powell also noted Khartoum's failure to cease and desist from the attacks on non-Arab groups and its continued obstruction of humanitarian aid even after having been repeatedly put on notice by other governments and by the United Nations.

Invoking Article VIII of the UNCG, Powell called upon the United Nations to undertake its own investigation. Thus, the only specific outcome of the genocide determination was the September 18 passage by the UN Security Council of Resolution 1564, which requested that the UN secretary-general appoint an International Commission of Inquiry to look into whether acts of genocide had in fact occurred and to identify perpetrators of violations of international humanitarian and human rights law. While awaiting the commission's report, the Security Council decided "to remain seized of the matter."

At the end of January 2005, the commission issued its report, which documented the Sudanese government's role in organizing, arming, and training the Janjaweed militia. Page after page of the voluminous report laid responsibility for serious 
violations of international humanitarian and human rights law at the government's doorstep. The commission concluded that the government and its allies bore primary responsibility for massive violence against civilians that had a pronounced ethnic dimension. Addressing the particular terms of the UNCG, the commission noted that its investigation

collected substantial and reliable material which tends to show the occurrence of systematic killing of civilians belonging to particular tribes, of large-scale causing of serious bodily or mental harm to members of the population belonging to certain tribes, and of massive and deliberate infliction on those tribes of conditions of life bringing about their physical destruction in whole or in part (for example by systematically destroying their villages and crops, by expelling them from their homes, and by looting their cattle). ${ }^{20}$

The commission believed that this evidence could establish the physical acts enumerated in Article II(a)-(c). ${ }^{21}$

But then the Commission explicitly "conclude[d] that the Government of Sudan has not pursued a policy of genocide" based on the absence of the required "intent to destroy." 22 Although the commission's report acknowledges that the scale of the atrocities, the systematic nature of the atrocities, and racially motivated statements by perpetrators indicated genocidal intent, it asserts that "other more indicative elements" pointed to a lack of intent. The commission identifies three elements supposed to be "more indicative." 23

First, in some unspecified number of villages, the attackers "refrained from exterminating the whole population." 24 As evidence, the commission refers to one group of villages in which the government commissioner and the leader of the Arab militias executed about 227 of some 1,200 people who were captured after the attack. Apparently, fifteen of the executed were on a written list brought by the perpetrators, seven were village leaders (omdas), and 205 were accused of being rebels. The commission's reference to the fact that the perpetrators did not "exterminat[e] the whole population" is puzzling. The plain language of the convention includes an intent to destroy a group "in part." The commission itself explains in a previous paragraph that international case law establishes that "the intent to destroy a group 'in part' requires the intention to destroy a 'considerable number of individuals' or 'a substantial part,' but not necessarily a 'very important part of the group."'25 The commission fails to offer any reason why 227 out of 1,200 is neither a "considerable number of individuals" (in relation to that sample) nor "a substantial part" of that sample, especially when the community leadership was particularly targeted. Moreover, it seems to take at face value the perpetrators' reported assertion that the 205 murdered villagers were rebels, leading the comission to distinguish between "the intent...to destroy an ethnic group as such" and "the intention to murder all those men they considered to be rebels." Yet, on just the previous page, the commission quotes a number of utterances in which the perpetrators used ethnic identity, racial epithets, and terms such as Torabora (slang for "rebels") interchangeably. ${ }^{26}$ The whole point of the government's campaign against the civilian population of non-Arab ethnic groups was equating ethnicity with rebellion, rendering it nonsensical to distinguish an intent to destroy those ethnic groups from an intent to murder rebels. The targets were, by the Sudanese government's apparent definition, one and the same. ${ }^{27}$

The second element cited by the commission as indicating a lack of genocidal intent is that the Sudanese government collects survivors of destroyed villages in camps for internally displaced persons (IDPs), where it "generally allows humanitarian 
organizations to help the population ... by providing food, clean water, medicines and logistical assistance." 28 This element begs the question of whether the direct violence (i.e., murdering and raping) was of sufficient scale to evince the intent to destroy the targeted groups "in part," even though there are survivors who were not murdered outright. And the commission offers no rationale explaining why this element should be more indicative of intent than the scale and systematic nature of direct violence. It also skirts the issues of government obstacles to humanitarian aid, which were reduced but not eliminated by concerted international pressure in mid-2004; continuing elevated mortality rates in these camps; and continuing attacks (meaning murder and rape) against those who venture out of the camps in search of essentials of life such as firewood, water, or food.

The third element identified by the commission is that some unspecified number of villages with a mixed ethnic composition had not been attacked at the time the commission was undertaking its investigation. It is difficult to know what to make of this assertion as the commission makes no effort to contextualize it. For example, it does not quantify the number of untouched villages in relation to the number of villages destroyed, or by relating the number of inhabitants of such villages to the number of civilians who were subject to murder, rape, or displacement. Just as importantly, previously unharmed villages were being attacked and destroyed during the time that the commission was researching and writing its report. ${ }^{29}$

The commission's final paragraph of analysis regarding intent is perhaps the most difficult to fathom. It recounts a single anecdote from "a reliable source" in which one man was not killed when "attackers"- there is no identification of these attackerstook 200 camels from him. By contrast, the man's younger brother resisted the theft of his one camel and was shot dead. "Clearly," the commission concludes, "in this instance the special intent to kill a member of a group to destroy the group as such was lacking, the murder being only motivated by the desire to appropriate cattle belonging to the inhabitants of the village." ${ }^{30}$ Perhaps the requisite intent was indeed missing in that one instance. But the relationship of that one instance to the overall situation-in which "pillaging and destruction ... appears to have been directed to bring about the destruction of the livelihoods and means of survival of" the targeted populations ${ }^{31}$ —is a mystery.

\section{Weighing the Evidence}

Although Powell and the UN's Commission of Inquiry operated from a largely similar factual base, they reached diametrically opposite conclusions on the question of genocide. One explanation for this may be an issue that neither addressed explicitly: the weight of evidence necessary to reach a conclusion. In these circumstances, how much evidence of genocidal intent-in terms of quality and credibility-is necessary relative to evidence of a lack of intent?

The commission hints that it applied an extremely high standard in assessing the evidence. "Courts and other bodies charged with establishing whether genocide has occurred," the report notes, "must however be very careful in the determination of subjective intent." 32 It then approvingly quotes the International Criminal Tribunal for the former Yugoslavia for the proposition that "[c]onvictions for genocide can be entered only where intent has been unequivocally established." ${ }^{33}$ In essence, the commission adopted for itself the standard that intent must be shown "beyond reasonable doubt" - the weight of evidence necessary to convict an individual in a criminal trial. ${ }^{34}$ This is the most exacting burden imaginable-an understandable 
burden for a prosecutor to bear when a court is deciding the life or liberty of an individual.

Viewed in the context of this burden, the commission's analysis on the issue of genocidal intent is less mysterious. The three "elements" it cites, though not particularly compelling, do cast some doubt on the existence of a genocidal intent on the part of the Sudanese government. One might well conclude that the evidence of genocidal intent that is adduced in the commission's report, though quite strong, does not establish such intent "beyond reasonable doubt."

But this standard is clearly wrong under these circumstances. The commission was not a court of law, nor was it adjudicating the fate of individual defendants. The liberty of an accused defendant did not turn on its decision. Quite to the contrary, the commission was called upon only to make a threshold finding on the basis of which the UN Security Council would decide whether to take additional action, including referring the situation to the International Criminal Court (ICC) for a full-fledged criminal investigation.

A review of the ICC Statute makes clear the commission's error in applying the "beyond reasonable doubt" standard. The statute contemplates several stages through which a case proceeds, each requiring that a separate weight of evidence be met. When a situation is referred to the ICC, the prosecutor is required to initiate an investigation unless "there is no reasonable basis to proceed." 35 Having conducted an investigation, the prosecutor may seek an arrest warrant if he or she can establish "reasonable grounds to believe that the person has committed a crime within the jurisdiction of the Court." 36 The court is next called upon to confirm the charges, which it will do if the prosecutor offers "sufficient evidence to establish substantial grounds to believe that the person committed the crime charged." 37 Finally, at trial, an individual can only be convicted if the court is "convinced of the guilt of the accused beyond reasonable doubt."38

Between "no reasonable basis to proceed" and "beyond reasonable doubt" lies a continuum along which the required weight of evidence steadily, and appropriately, mounts as the process moves forward. To eliminate that continuum and require a prosecutor to establish guilt beyond a reasonable doubt as a condition of launching an investigation would be nonsensical. Yet that is the standard of proof apparently applied by the commission, in spite of the fact that its investigation was prefatory to any judicial action. The commission's application of this standard is all the more erroneous in light of the constraints placed upon it by the amount of time available, ${ }^{39}$ as well as the continued perpetration of the very crimes it was supposed to investigate. It was not in any conceivable position to reach a conclusion "beyond reasonable doubt" on an issue as complex and problematic as genocidal intent.

As previously mentioned, Powell did not articulate what weight of evidence he looked for in making his determination. But the tenor of his analysis, which emphasized the necessarily limited nature of the ADT investigation and other information available, suggests that he was, in essence, asserting a reasonable basis for concluding that the Sudanese government and its Janjaweed allies had committed genocide. The additional facts established by the commission confirm the existence of that reasonable basis.

\section{Politics, Not Law}

If a determination of genocide is to be a predicate for further action-whether the launching of a judicial investigation or the launching of humanitarian intervention or 
anything else-the weight of evidence necessary to support that finding cannot be "beyond reasonable doubt." That level of evidence will simply not be available until those in danger are long dead. Commissions or diplomats or politicians can take endless refuge behind every fig leaf of doubt. Outside of a formal judicial process, it only makes sense to speak of a reasonable basis to believe that genocide is occurring or threatened.

But the ultimate irony of the UNCG is that, when it comes to "preventing" or "suppressing" genocide, a determination of genocide does not trigger any form of action whatsoever. If this was not already clear from the convention's plain language, it was made starkly so by Secretary Powell's assertion on 9 September 2004, that "no new action is dictated by this determination." 40 Powell's affirmative determination and the commission's negative one had the same effect. The UNCG, for all its supposed moral force, in actuality contributes little to prevention or suppression.

Powell's request to the United Nations, pursuant to the permissive provisions of Article VIII, to launch an investigation was made "with a view to ensuring accountability" - that is, punishment. Yet punishment is not the same as prevention or suppression. It inevitably occurs, if at all, after the time for preventing or suppressing has passed. One may argue that a sufficiently real threat of punishment may have a deterrent effect powerful enough to stop ongoing acts of genocide or to prevent imminent acts. But that argument is purely theoretical. And the continued deterioration of the situation in Darfur months after the Security Council referred the situation to the ICC suggests that the theory may be faulty.

Powell's request under Article VIII of the UNCG, Security Council Resolution 1564, the UN Commission of Inquiry's investigation, the commission's analysis of genocidal intent-all were couched in the language of law drawn from the UNCG and other legal instruments. But in a very real sense, the whole process was a burlesque of law. Essentially, everything documented by the commission was not only knowable but actually known months and months before the commission was even formed. Even as the commission was conducting its investigation, the government of Sudan was continuing to perpetrate the very crimes that the commission was analyzing. During the whole time that the basic facts have been known, and even since the commission released its report, no effective action has been taken by the so-called international community actually to stop the killing and the rapes. It is as though one man is clubbing another on a street corner while bystanders respond with a prolonged reflection on whether the incident is premeditated murder or simple assault or even self-defense. Meanwhile, the crime continues.

Powell, near the end of his testimony in September 2004, told the Senate committee that "[w]e have been doing everything we can to get the Sudanese government to act responsibly." He certainly deserves credit for going out of his way to identify himself with a difficult issue, and there are many officials in the State Department and elsewhere in the US government who have been working diligently on Darfur. But the definition of "everything we can" is ultimately a political question, not a legal one. And effective prevention and suppression of "genocide"-or other forms of mass atrocities against civilian populations-will not occur through a sense of obligation under international law but as the result of political pressure on governments by their citizens. As Samantha Power has argued, politicians will act to stop mass killing when the political cost of inaction outweighs the risk of acting. ${ }^{41}$

In preparation for the 2005 World Summit, held to mark the sixtieth anniversary of the United Nations, a draft General Assembly resolution was circulated that would 
have recognized an "obligation" of UN members to use various peaceful means "to help protect populations from genocide, war crimes, ethnic cleansing and crimes against humanity." The draft would also have recognized a "shared responsibility" to take collective coercive action under the UN Charter if peaceful means fail and national authorities are "unwilling or unable to protect their populations." In the end, the first passage was watered down to acknowledge a "responsibility" to use "appropriate diplomatic, humanitarian and other peaceful means." The second passage jettisoned the notion of a responsibility to act and replaced it with the statement that

we are prepared to take collective action ... on a case-by-case basis ... should peaceful means be inadequate and national authorities are manifestly failing to protect their populations from genocide, war crimes, ethnic cleansing and crimes against humanity. ${ }^{42}$

Being "prepared" to do something case-by-case is in fact consistent with actually not doing anything from case to case.

It may well be that the final language approved by the UN General Assembly represents a normative advance. It is certainly more explicit than anything in the UNCG. It also broadens the circumstances in which action may be taken beyond the narrow category of genocide by adding war crimes, ethnic cleansing, and crimes against humanity, which may forestall endless arguments about the complex and problematic notion of genocidal intent. But the final language underscores the fact that the prevention and suppression of genocide and other mass atrocities will never be accomplished by the international community, or by members of that community, through a sense of legal obligation. It will happen, if at all, as a result of political or practical necessity. Only by recognizing and acting on this reality can we hope to end the heartbreaking irony of a universally condemned crime that is allowed to occur in broad daylight.

\section{Notes}

1. The views expressed are those of the author and not necessarily those of the Committee on Conscience or the United States Holocaust Memorial Museum.

2. Diane Orentlicher, "Genocide," in Crimes of War, ed. Roy Gutman and David Rieff, 153-57 (New York: W.W. Norton, 1999), 153.

3. Ibid.

4. Raphael Lemkin, Axis Rule in Occupied Europe: Laws of Occupation; Analysis of Government; Proposals for Redress (Washington, DC: Carnegie Endowment for International Peace, 1944), 79.

5. Ibid.

6. Samantha Power, "A Problem from Hell": America and the Age of Genocide (New York: Basic Books, 2002), 30-85.

7. Indictment: United States of America et al. v. Hermann Goering et al., The Avalon Project: Nuremberg Trial Proceedings, vol. 1 (International Military Tribunal, 1945), http:// www.yale.edu/lawweb/avalon/imt/proc/count.htm (accessed 21 April 2006), para. VIII(A). The four counts in the indictment charged the defendants with crimes against the peace, war crimes, crimes against humanity, and conspiracy to commit the other crimes.

8. The Crime of Genocide, UN General Assembly Resolution 96(I), UN Doc. A/64/Add. 1 (11 December 1946), 188-89, http://daccessdds.un.org/doc/RESOLUTION/GEN/NR0/033/ 47/IMG/NR003347.pdf (accessed 21 April 2006).

9. Convention on Prevention and Punishment of the Crime of Genocide, 9 December 1948, 78 U.N.T.S. 277, http://www.unhchr.ch/html/menu3/b/p_genoci.htm (accessed 21 April 2006).

10. W. Schabas, Genocide in International Law: The Crime of Crimes (Cambridge: Cambridge University Press, 2000), 217-21. 
11. This idea came to fruition in July 2002 with the creation of the International Criminal Court. By January 2006, 100 countries had become members of the court. Neither the United States nor Sudan is a member of the court.

12. It is now widely, though not unanimously, accepted as a matter of customary international law that genocide is subject to "universal jurisdiction," meaning that the crime can be adjudicated in any national court without regard to territorial or other connections. Schabas, Genocide in International Law, 353-68.

13. See, e.g., Stephen J. Toope, "Does International Law Impose a Duty upon the UN to Prevent Genocide?" McGill Law Journal 46 (2000): 187-94, 192-93.

14. Application of the Convention on the Prevention and Punishment of the Crime of Genocide (Bosnia and Herzogovina v. Yugoslavia (Serbia and Montenegro)), Further Requests for the Indication of Provisional Measures, International Court of Justice (1993), separate opinion of Judge Elihu Lauterpacht, para. 115.

15. US Department of State, "Has Genocide Occurred in Rwanda?" (action memorandum, May 1994), http://www.gwu.edu/\%7Ensarchiv/NSAEBB/NSAEBB53/rw052194.pdf (accessed 21 April 2006).

16. Colin Powell, "The Crisis in Darfur" (written remarks before the Senate Foreign Relations Committee, 9 September 2004), http://www.state.gov/secretary/former/powell/remarks/ 36032.htm (accessed 21 April 2006).

17. Prosecutor v. Akayesu, Judgment, ICTR-96-4-T (2 September 1998), paras. 523-24; Prosecutor v. Musema, Judgment and Sentence, ICTR-96-13-A (January 27, 2000), para. 166.

18. Colin Powell, "The Crisis in Darfur" (testimony before the Senate Foreign Relations Committee, 9 September 2004), http://www.state.gov/secretary/former/powell/remarks/ 36042.htm (accessed 21 April 2006).

19. US Department of State, Documenting Atrocities in Darfur (Washington, DC: Bureau of Democracy, Human Rights and Labor and Bureau of Intelligence and Research), http://www.state.gov/g/drl/rls/36028.htm (accessed 21 April 2006), 4.

20. Report of the International Commission of Inquiry on Darfur to the United Nations Secretary-General (25 January 2005), http://www.un.org/News/dh/sudan/com_inq_ darfur.pdf (accessed 19 April 2006) [COI Report], para. 507.

21. Ibid., para. 518. The commission also addressed the issue of whether the targeted "tribal" groups are of the type ("national, ethnical, racial or religious") protected by the UNCG and concluded that they are. Ibid., paras. 508-12). This is a more complicated question than might first appear (see, e.g., Schabas, Genocide in International Law, 109-14), but it does not ultimately seem to be an issue with regard to Darfur.

22. Ibid. At the same time, the commission conceded that individuals, including government officials, may in fact have acted with genocidal intent (para. 520), begging the difficult question of how many government officials must harbor such intent before it is attributed to the state itself.

23. Ibid., para 513.

24. Ibid.

25. Ibid., para 492 .

26. Ibid., note 189: "Epithets that eyewitnesses or victims reported to the Commission included the following: 'This is your end. The Government armed me.' 'You are Massalit [a non-Arab ethnic group], why do you come here, why do you take our grass? You will not take anything today.' 'You will not stay in this country.' 'Destroy the Torabora.' 'You are Zhagawa tribes [a non-Arab ethnic group], you are slaves."

27. The commission itself, as well as the State Department's ADT, found little or no evidence of rebel activity in villages that were attacked by the Sudanese government and its militia allies.

28. COI Report, para. 515.

29. Brian Steidle, "In Darfur, My Camera Was Not Nearly Enough," The Washington Post, 2 March 2005, http://www.ushmm.org/conscience/alert/darfur/steidle (accessed 
21 April 2006). One of the pictures brought back from Darfur by Steidle, a former US Marine who served on the African Union monitoring team, is of the body of a boy who looks about two years old, killed when his village was attacked. The date stamp on the photo is $2005 / 01 / 15$, ten days before the commission submitted its report to the secretary-general.

30. COI Report, para. 517.

31. Ibid., para. 638.

32. Ibid., para. 503.

33. Ibid.

34. Rome Statute of the International Criminal Court, UN Doc. A/CONF.183/9 (1998), http:// www.icc-cpi.int/library/about/officialjournal/Rome_Statute_120704-EN.pdf (accessed 21 April 2006), art. 66.3.

35. Ibid., art. 53.1 (emphasis added).

36. Ibid., art. 58 (emphasis added).

37. Ibid., art. 61 (emphasis added).

38. Ibid., art. 66.3 (emphasis added).

39. The secretary-general requested that the commission report back to him within three months of its creation. COI Report, para. 1.

40. Powell, "Crisis in Darfur" (written remarks), 5.

41. Power, "A Problem from Hell", 510-11.

42. 2005 World Summit Outcome, UN General Assembly Resolution 60/1, UN Doc. A/Res/60/1 (2005), http://unpan1.un.org/intradoc/groups/public/documents/UN/UNPAN021752.pdf (accessed 21 April 2006), para. 139. 


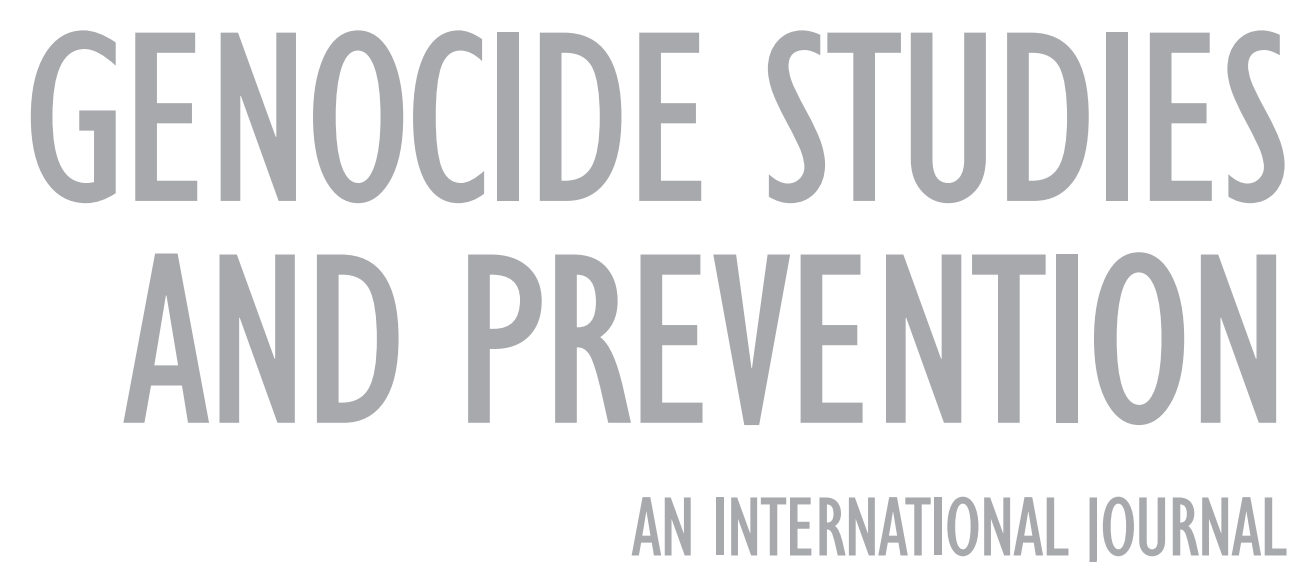

